\title{
PENGARUH KARAKTERISTIK TOKO DAN PRODUK BAGI KONSUMEN DI INDONESIA TERHADAP PEMBELIAN IMPULSIF
}

\author{
Aditya Halim Perdana Kusuma Putra ${ }^{1 *}$,Syahnur Said ${ }^{2}$, Sabri Hasan ${ }^{2}$ \\ ${ }^{1}$ STIM Lasharan Jaya Makassar \\ ${ }^{2}$ Fakultas Ekonomi, Universitas Muslim Indonesia \\ *adityatrojhan@gmail.com
}

\begin{abstract}
Impulsive buying tendencies can be found in shopping centers such as malls. The number of malls also cause consumer lifestyles change. Impulsive behavior of puchases is influenced by product characteristics and store characteristics. The purpose of this study is to determine whether the characteristics of stores and products affect the consumer's impulse purchases at malls in Indonesia. This study examines as 435 respondents with descriptive quantitative approach. Questionnaires are disseminated by online system. Data analysis uses a multiple linear regression. Results of this study shows the characteristics of the store and product characteristics significantly affect the impulsive buying.
\end{abstract}

Keywords: Store Characteristic, Product Characteristic, Impulsive Buying

\section{PENDAHULUAN}

Perilaku pembelian konsumen yang terjadi di era sekarang ini sangat erat kaitannya dengan pola konsumtif yang secara massal terjadi di sekeliling kita, baik di wilayah pedesaan atau di wilayah perkotaan. Hal ini seolah menjadi tantangan tersendiri di dalam mengendalikan pertarungan antara keinginan untuk memenuhi segala hasrat kebutuhan baik yang bersifat primer, sekunder maupun tersier. Fenomena mengenai pembelian irrasional tersebut termasuk dalam kategori Urban Disease. Urban Disease di dalam perilaku belanja konsumen lahir karena dipicu oleh perkembangan ritel modern. Perilaku konsumen di Indonesia menyangkut kebiasaan dan gaya hidup, terutama kebiasaan makan, gaya mengkonsumsi, bahkan perilaku konsumen dalam mengunjungi pusat perbelanjaan (Mars, 2015). Pada tahun 2011 penelitian yang dilakukan di beberapa kota besar di Indonesia antara lain Jakarta, Bandung, Surabaya, Makassar dan Medan menyebutkan bahwa sebanyak $21 \%$ pembeli tidak pernah membuat rencana didalam berbelanja (Nielsen, 2013). Perilaku konsumen yang impulsif dominan dilakukan oleh generasi millennial (CNN Indonesia, 2015) dengan menyebutkan angka sebesar $50 \%$ generasi millennial merupakan pelanggan yang paling impulsif di Asia Pasifik.

Pada proses pembelian yang sifatnya rasional, konsumen melakukan pertimbangan dengan cermat dan mengevaluasi sifat produk secara fungsional, terkadang muncul pembelian yang didasari oleh faktor emosi. Pembelian ini bersifat hedonic, sehingga objek konsumsi dipandang secara simbolis dan berhubungan dengan respon emosi (Hirschman \& Holbrook dalam Engel dkk, 1995). Kecenderungan pembelian impulsif dapat dijumpai pada pusat perbelanjaan seperti mall. Banyaknya mall juga menyebabkan gaya hidup konsumen mengalami perubahan. Pertumbuhan mall di Indonesia pada tahun 2011 tercatat tumbuh 38\% dibandingkan tahun 2009 (Andina 
Meryani, 2011). Jumlah mall di Indonesia di tahun 2014 adalah sebanyak 250 mall yang terbesar diseluruh Indonesia (Detik finance, 2014), yang terus berkembang hingga kuartal tiga yang telah dibangun dengan total area 4,5 juta meter persegi di tahun 2016 serta mengalami lagi peningkatan pembangunan sekitar 2\% sampai tahun 2017 (Marketeers.com, 2017). Ibukota Jakarta sebagai lokasi dengan jumlah mall terbanyak di Indonesia bahkan dunia yang luasnya mencapai 9 kali luas vatikan roma (Vebma.com, 2017) dan sekitar 3 mall diantaranya masuk dalam daftar 100 mall paling besar didunia (bintang.com, 2015). Hasil survei Middle Class Institute yang menyatakan bahwa $74.4 \%$ resepondennya menghabiskan akhir pekan mereka di Mall (Dosomethingindonesia.org, 2016). Selain berbelanja, cuci mata, mall juga menjadi tempat rekreasi dan bersantai.

Data dari tahun 2007 - 2017 menyebutkan bahwa jumlah pusat perbelanjaan di Indonesia mengalami peningkatan pembangunan baik pada sektor mall, hypermarket dan supermarket, data tersebut seperti dibawah ini :

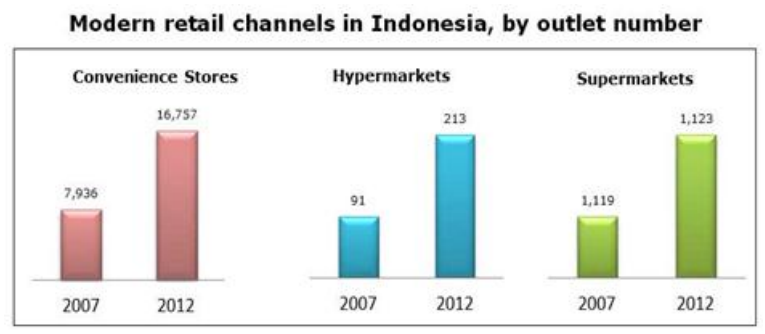

Gambar. 1 Perkembangan Retail Modern di Indonesia 2007-2012

Data ditahun 2017 menyatakan peningkatan pembangunan mall dan pusat perbelanjaan diberbagai kota di Indonesia juga mengalami peningkatan seperti dibawah ini :

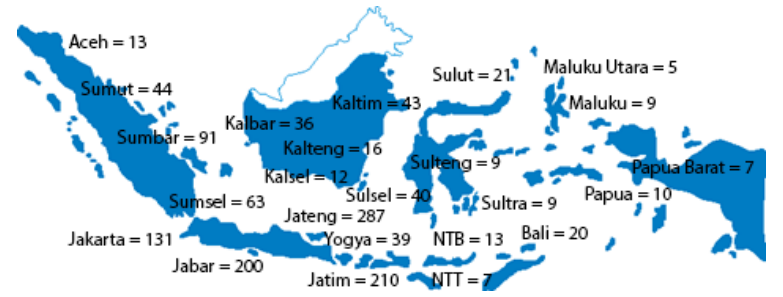

Gambar 2. Pertumbuhan Mall dan Pusat Perbelanjaan di Indonesia Tahun 2017
Perbandingan pertumbuhan mall di Indonesia dari tahun 2011 ke tahun 2017 menyatakan perbandingan sebagai berikut :

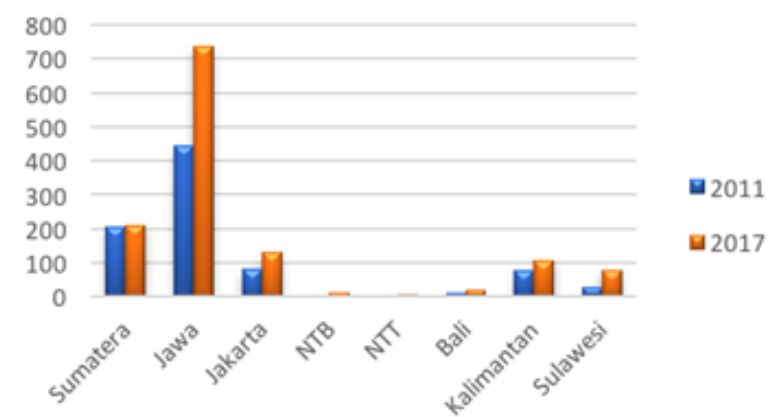

Gambar 3. Perbandingan Mall dan Pusat Perbelanjaan di Indonesia Tahun 20112017

Salah satu pemicu lahirnya kebiasaan berbelanja secara impulsif salah satunya ditenggarai oleh karakteristik toko. Karakteristik toko tersebut termasuk didalamnya adalah peran daripada pelayan toko yang merupakan salah satu dimensi pokok yang membedakan antara satu toko dengan toko yang lainnya. Pelayan toko yang handal mampu menarik konsumen untuk memutuskan berbelanja, tenaga penjual yang baik memberikan kesan positif kepada calon pembeli dan konsumennya, tenaga penjual merupakan intanggible asset bagi perusahaan. Secara implementasi pelayan toko yang baik dan sudah terlatih dapat mengurangi tingkat frustasi pelanggan melalui pemanduan dan pengarahan kepada pelanggan di dalam proses pembayaran, keramahan pelayan toko juga dapat mendorong konsumen menjadi impulsif secara aktif. kehadiran pelayan toko yang handal juga dapat mengurangi tingkat frustasi konsumen yang hendak berbelanja lewat penyajian informasi kepada konsumen (Ditmar, et.al, 1996). Selain daripada itu dimensi lain daripada karakteristik toko yakni layout toko meliputi tema yang diusung lewat pemilihan warna interior, tema desain dan juga musik memberikan kesan yang berbeda dan dipercaya dapat membuat konsumen menjadi lebih betah selama berbelanja. Layout toko yang menarik akan menjamin kesan yang positif bagi pengunjung. Stimulasi daripada layout toko 
seperti penyajian musik, pewangi ruangan dan tema desain yang di usung memainkan peran penting dalam memicu aktivitas pembelian impulsif. Rangsangan yang dihasilkan dari layout dan atmosfer toko memberikan efek emosional kepada konsumen.

Karakteristik toko termasuk di dalamnya layout toko, kehadiran pelayan toko, suasana toko dan type toko itu sendiri. Layout Toko : Marketer yang baik harusnya menghadirkan layout toko yang baik untuk memberikan kenyamanan kepada konsumen (Crowford and Malewar, 2003). Kehadiran Pelayan Toko : Pelayan toko yang baik dan sudah terlatih dapat mengurangi tingkat frustasi pelanggan melalui pemanduan dan pengarahan kepada pelanggan didalam proses pembayaran dan perilaku pembelian impulsif secara aktif Suasana Toko : Manajer toko dapat melihat melalui angka dari variabel desain lingkungan untuk meningkatkan rangsangan di dalam tokonya. Sebagai contoh tempo musik yang tinggi dan volume musik yang tinggi untuk meningkatkan gairah berbelanja. Warna yang cenderung hangat misalnya orange, merah dan kuning semuanya berelaborasi meningkatkan gairah berbelanja. Misalnya pengharum ruangan misalnya pengharum rasa anggur dan lemon juga meningkatkan rangsangan pada pembelian.

Hasil penelitian Clover $\mathrm{T}$ Vernon (1950), menyatakan bahwa beberapa kategori produk laku terjual dengan cara yang impulsif atau pembeli membeli beberapa kategori produk tersebut tanpa perencanaan, Stern di tahun 1962 dari hasil penelitiannya menyatakan bahwa mendefenisikan perilaku pembelian impulsif konsumen berdasarkan atas perencanaan, tidak terencana atau niat yang memang impulsif. Beberapa jenis kategori produk tertentu dapat diprediksi membuat orang menjadi impulsif sehingga membelinya. Rook ditahun 1985 memperkenalkan konsep daripada pembelian impulsif sebagai sifat daripada gaya hidup yang dapat dikaitkan sebagai bentuk sikap materealisme, mencari sensasi dan sebagai aspek untuk rekreasi yang didapat melalui belanja. Abratt \& Goodey ditahun 1990 menyatakan bahwa stimulus di dalam toko seperti POP (Point of Purchase) seperti visual merchandising dapat meningkatkan potensi pembelian impulsif seseorang. POP (point of purchase) salah satu contohnya adalah display produk yang diletakkan di dekat kasir. Han, et.al ditahun 1991 menyatakan bahwa orientasi terhadap fashion, lebih memiliki kecenderungan seseorang untuk berperilaku secara impulsif. Hoch \& Loewenstein di tahun 1991 menyatakan bahwa bukan produk yang membuat orang menjadi impulsif akan tetapi personal konsumen itu sendiri yang sulit mengendalikan dirinya. Hal ini juga membantah hasil penelitian daripada Clover (1950) dan Stern (1962). Wood ditahun 1998 menyatakan bahwa seseorang yang berada pada SES (Socio economy status) level rendah atau yang memiliki pendapatan perkapita rendah memuaskan dirinya untuk berbelanja secara impulsif. Bayley \& Nancarrow ditahun 1998 menyatakan bahwa pembelian impulsif merupakan proses pembelian yang kompleks, proses pengambilan keputusan yang cepat saat belanja, mencegah pertimbangan informasi secara sengaja, atau karena berbagai pilihan alternatif. Jones, et.al ditahun 2003 menyatakan bahwa produk secara spesifik berdampak signifikan dan merupakan faktor pendukung yang penting didalam tendensi seseorang untuk berperilaku impulsif.

Faktor pendukung lainnya yang dapat memicu seseorang untuk berperilaku impulsif ialah peran daripada produk itu sendiri. Phillip Kotler, 2009 berpendapat bahwa dalam membentuk penawaran pasar terhadap kegiatan-kegiatan yang dilakukan oleh perusahaan salah satunya adalah harus menjawab karakteristik produk dan bagaimana seorang pemasaran mengklasifikasikan produknya. Secara luas produk merupakan sesuatu yang dapat ditawarkan kepada konsumen untuk memuaskan keinginan atau kebutuhan termasuk didalamnya barang yang bersifat fisik dan jasa. Karakteristik produk dapat diklasifikasikan dan memberikan kesan 
kepada penggunanya melalui cerminan dari pada manfaat inti (Benefit Core) daripada produk yang disajikan kepada mereka. Manfaat inti dalam hal ini salah satunya ialah daya tahan produk itu sendiri (Durability). Ketahanan tentu akan memberikan perbedaan yang signifikan antara barang yang tahan lama dengan barang yang tidak tahan lama baik berupa barang fisik maupun jasa. Daya tahan produk yang signifikan melahirkan image daripada produk itu sendiri dan dapat berimbas kepada citra merek produk tersebut.

Produk dengan anggapan memiliki daya tahan yang lama, memberikan gambaran kualitas produk tersebut adalah baik atau berkualitas. Sedangkan produk yang tidak bertahan lama akan dianggap sebagai produk yang tidak berkualitas. Kriteria karakteristik produk juga dapat dilihat daripada sejauh mana sikap possesif seseorang yang condong terhadap satu merek tertentu yang menganggap produk yang ia miliki dapat di deskripsikan lebih baik ketimbang merek produk yang lain. Possesif merek juga merupakan dimensi daripada brand image yang di dalam dunia marketing dikenal sebagai loyalitas merek. Dibanyak fakta yang ada, loyalitas merek menjamin efek yang luar biasa terhadap perluasan pangsa pasar. Tidak sedikit daripada konsumen menganggap merek tertentu lebih "Wow" daripada merek yang lain, atau merek yang telah hadir lebih dulu cenderung lebih baik daripada merek yang baru dijual dipasaran, bahkan merek dengan produk yang dipakai secara massal oleh banyak orang dianggap merek yang lebih berkualitas daripada merek yang kurang begitu diminati atau kurang dimiliki oleh orang lain. Tanpa pembuktian yang jelas seolah pernyataan tersebut diaminkan dan membentuk persepsi alam bawah sadar baik perseorangan maupun kolektif didalam melihat merek suatu produk. Tidak dapat dipungkiri bahwa terdapat segelintir merek yang memberikan prestise lebih kepada penggunanya, prestise tersebut akan semakin meningkat jika pengguna produk tersebut dianggap terbatas (Limited Edition). Oleh sebab itu terjadilah penerapan harga yang sangat jauh berbeda dan diyakini bahwa "Ada harga, ada kualitas". Harga yang mahal pada suatu produk dan merek seolah memberikan kesan bahwa produk tersebut menjamin prestise yang lebih tinggi. Mengenai dampak suatu merek membentuk nilai posesif seseorang merupakan fakta didunia modern saat ini bahwa merek tertentu yang begitu dinantinantikan dapat memberikan stimulus bagi seseorang yang dapat berperilaku secara impulsif.

Produk tertentu yang dibeli cenderung lebih impulsif daripada produk yang lain hal itu dilatarbelakangi oleh kemungkinan bahwa suatu produk akan dibeli karena dorongan tergantung pada kategori produk dan harga produk itu sendiri karena produk terbagi dua kategori yaitu produk hedonis atau produk fungsional. Produk hedonis terutama dikonsumsi untuk manfaat hedonik, sementara produk fungsional yang dikonsumsi untuk manfaat utilitarian (Babin et al., 1994). Telah ditemukan bahwa pembelian impulsif terjadi lebih dalam kasus produk hedonis karena simbolik semata. Selain daripada itu factor harga merupakan faktor penentu penting dari pembelian impulsif (Wong dan Zhou, 2003). Lebih khusus, konsumen cenderung lebih impulsif ketika ada harga khusus dalam penjualan atau diskon produk, kebutuhan marginal rendah untuk item, masa kadaluarsa produk pendek, ukuran yang lebih kecil, dan kemudahan penyimpanan barang itu sendiri juga memicu terjadinya pembelian impulsif.

Kecenderungan pembelian impulsif lahir dari berbagai faktor yang merangsang seseorang baik secara personal maupun kolektif yang dirangkum sebagai faktor internal dan eksternal pada konsumen. Faktor internal konsumen antara lain karakteristik konsumen yang yakni faktor sensasi kenikmatan belanja. Seorang yang impulsif didalam berbelanja maka ia akan menemukan kenyamanan dan perasaan nikmat selama berbelanja (Beatty \& ferrel, 1998). Kecenderungan pembelian impulsif ditandai dari perasaan senang antusias dan gembira selama berbelanja (Weinberg \& 
gotwald, 1982). Bahkan seorang konsumen yang memiliki respon emosional yang lebih positif terhadap lingkungan ritel itu lebih cenderung melakukan pembelian impulsif (Chang, et.al, 2011).

Pada penelitian yang dilakukan oleh Wood (1998) menyatakan bahwa kecenderungan perilaku impulsif seseorang berada pada level usia 18-39 tahun. Sedangkan untuk jenis kelamin, kecenderungan perilaku impulsif seseorang dominan ditemukan pada wanita Kim (2003). Pendapat tersebut juga dibenarkan dari hasil penelitian oleh Aditya (2012) yang menemukan fakta bahwa sebanyak $55,7 \%$ sedangkan pria $44,3 \%$ yang memiliki kecenderungan untuk melakukan pembelian impulsif. Angka tersebut jauh berkurang dari fakta sebelumnya yang dikemukakan oleh Ditmar dan Drury (2000) yang menyatakan bahwa sebanyak $84,8 \%$ wanita lebih dominan berpeluang untuk berperilaku impulsif. Perempuan lebih melihat dari faktor nilai elemen kepemilikan dan emosional serta alasan pergaulan, sedangkan laki-laki lebih kepada pertimbangan alasan keuangan dan fungsi dari produk itu sendiri. Dittmar \& Drury (2000).

Penelitian ini diteliti di beberapa mall kota besar di Indonesia yakni Jakarta, Bandung, Medan, Palembang, dan Makassar. Hal tersebut juga merupakan beberapa sampel penelitian oleh Mars di tahun 2011 dan hasil penelitiannya menyatakan bahwa dari $39 \%$ pebelanja di mall terdapat sebanyak $21 \%$ pembeli yang tidak pernah membuat rencana belanja mereka sedangkan hal ini terjadi peningkatan dibandingkan tahun 2013. Terutama di Jakarta perkembangan mall terasa sangat tidak berimbang dengan lahan peruntukan umum lagi, Jumlah mall di Indonesia di tahun 2014 adalah sebanyak 250 mall yang terbesar diseluruh Indonesia. Detik finance (2014), yang terus berkembang hingga kuartal tiga yang telah dibangun dengan total area 4,5 juta meter persegi di tahun 2016 serta mengalami lagi peningkatan pembangunan sekitar 2\% sampai tahun 2017. (Marketing.co.id , 2017). Ibukota Jakarta sebagai lokasi dengan jumlah mall terbanyak di Indonesia bahkan dunia yang luasnya mencapai 9 kali luas vatikan roma dan sekitar 3 mall diantaranya masuk dalam daftar 100 mall paling besar didunia.

Penelitian ini mengalamatkan beberapa pokok rumusan permasalahan yang kemudian nantinya diharapkan dapat menjadi acuan untuk penelitian lebih lanjut mengenai fenomena pembelian impulsif itu sendiri antara lain: 1) menjadi diskusi terhadap intrepertasi keilmuan social terhadap perilaku konsumen; 2) menjadi Critical Review di masyarakat terkait pembelian impulsif. Oleh karena itu, peneliti tertarik untuk meneliti lebih mendalam mengenai pembelian impulsif tersebut yang terjadi pada masyarakat perkotaan di Indonesia didalam perilaku berbelanja dipusat perbelanjaan (Mall) dan melihat sejauh mana fenomena pembelian impulsif ini berkembang dimasyarakat melalui pendekatan faktor internal dan eksternal konsumen

\section{METODE}

Objek penelitian adalah konsumen mall di Indonesia sebanyak 435 responden dibeberapa kota besar di Indonesia (Jakarta, Palembang, Makassar, Bandung) yang diambil secara acak berdasarkan metode insidential random sampling dengan rentan usia mulai dari 18 tahun - 51 tahun keatas, rentan pendapatan $(<\mathrm{Rp} .2$ Juta rupiah diatas Rp. 5 juta), rentan pendidikan (SMU, Diploma, S1, S2, dan S3), Pengambilan sampel dengan menggunakan kuesioner online, metode analisis data menggunakan regresi linear.

Skala pengukuran variable menggunakan Skala Likert (1-5) yakni sangat setuju (5), setuju (4), netral (3), tidak setuju (2), sangat tidak setuju (1). Sedangkan alat uji analisis data menggunakan SmartPLS.

Kerangka konseptual penelitian ini adalah sebagai berikut : 


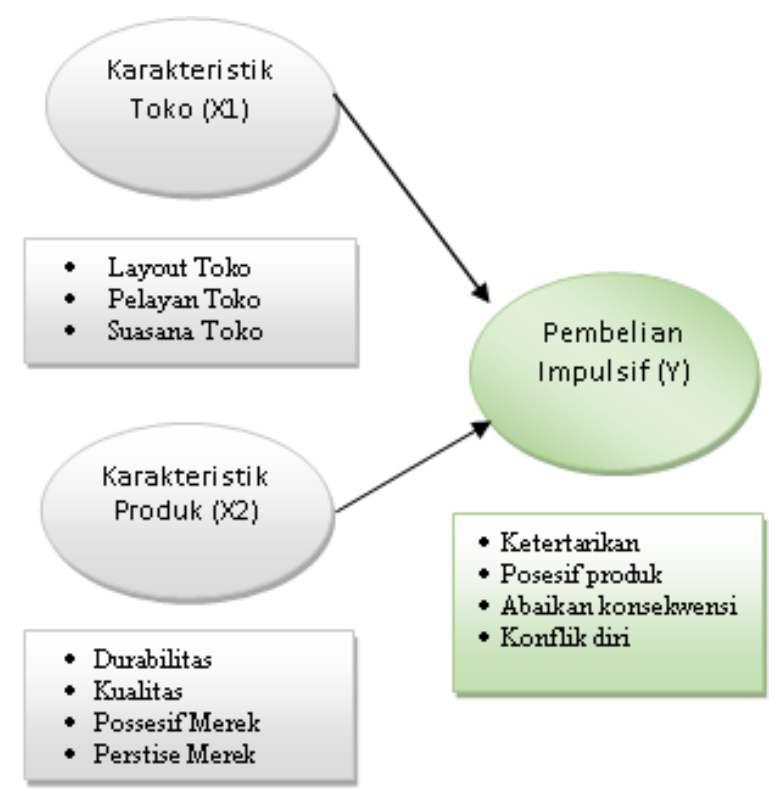

Gambar 4. Kerangka Konseptual Penelitian

Definisi operasional variabel pada penelitian ini adalah antara lain :

a. Karakteristik Toko (X1) : merupakan faktor eksternal konsumen, dengan indikator pengukuran adalah :

- X1.1 : Layout Toko Dholakia (2000), Kim (2003), Crowford \& Malewar, (2003)

- X1.2 : Kehadiran Pelayan Toko. Kim (2003), Wahida (2010)

- X1.3 : Suasana Toko Kim (2003), Wahida (2010).

b. Karakteristik Produk (X2): Produk tertentu yang dibeli cenderung lebih impulsif daripada produk yang lain. Hal itu dilatarbelakangi oleh kemungkinan bahwa suatu produk akan dibeli. Dengan dimensi pengukuran adalah :

- X2.1 : Durabilitas merek

- X2.2 : Kualitas Merek

- X2.3 : Posessif Merek

- X2.4 : Prestise Merek

c. Pembelian Impulsif (Y) adalah pembelian yang dilakukan tanpa perencanaan, segera atau memutuskan pembelian ditempat. Merujuk kepada teori Clover (1950) dan Rook (1987), dengan dimensi pengukuran sebagai berikut :

- Y.1 : Ketertarikan

- Y.2 : Possesif Produk

- Y3 : Mengabaikan Konsekwensi

- Y.4 : Konflik Diri
Hipotesis didalam penelitian ini adalah Karakteristik toko dan karakteristik produk berpengaruh terhadap kecenderungan pembelian impulsif konsumen mall di Indonesia.

\section{HASIL DAN PEMBAHASAN Hasil}

Berdasarkan jenis kelamin responden yakni Usia 18 - 25 tahun sebanyak 264 orang, Usia 26 - 33 tahun sebanyak 132 orang, Usia 34 - 41 tahun sebanyak 24 orang, Usia $41-48$ tahun sebanyak 11 orang, Usia 49 - 56 tahun sebanyak 3 orang. Berdasarkan pendapatan yakni Dibawah 2 juta sebesar 44,1\%, Rp. 2 juta - 5 juta sebesar 35,9\%, Rp. 5 juta -8 juta sebesar $9 \%$, Rp. 8 juta -12 juta sebesar $5,7 \%$, diatas Rp. 12 juta dengan presentase sebesar 5,3\%. Berdasarkan tingkat pendidikan yakni SMU Sederajat 48\%, Diploma (I,II,III,IV) 6,3\%, Strata-1 (S1) 35,8\%, Strata-2 (S2) 7,8\%, Strata-3 (S3) 0.6\%. Selanjutnya berdasarkan statistik suku dan etnis responden yang mengisi angket ini antara lain : Ambon (3 orang), Bali (5 orang), Banjar (4 orang), Batak (6 orang), Bima (2 orang), Bugis (60 orang), Buton (15 orang), Dayak (5 orang), Gorontalo (5 Orang), Jawa (50 orang), kaili (6 orang), Makassar (70 orang), Maluku (2 orang), Manado (7 orang), Mandar (21 orang), Manggarai (2 orang), Melayu (11 orang), Minang (8 orang), Muna (7 orang), Sunda (32 orang), Ternate (3 orang), Tionghoa (21 orang), Tolaki (6 orang), Toraja (18 orang), Campuran (56 orang), Betawi ( 9 orang). Sehingga total responden didalam penelitian ini adalah berjumlah 435 orang.

Tabel 1. Konstruk Validitas dan Reliabilitas

\begin{tabular}{|l|c|c|c|c|}
\hline & $\begin{array}{c}\text { Cronbach } \\
\text { Alpha }\end{array}$ & rhoA & $\begin{array}{c}\text { Composite } \\
\text { Reliability }\end{array}$ & (AVE) \\
\hline Produk & 0.646 & 0.664 & 0.790 & 0.587 \\
\hline Impulsif Buying & 0.713 & 0.713 & 0.822 & 0.536 \\
\hline Toko & 0.696 & 0.675 & 0.699 & 0.539 \\
\hline
\end{tabular}

Sumber : data diolah 
Pada tabel 1. AVE, Cronbach Alpha, Composite Reliability di atas menunjukkan bahwa semua konstruk memenuhi syarat. Discriminant Validity dari model pengukuran dengan refleksif indicator dinilai berdasarkan crossloading pengukuran dengan konstruk. Jika korelasi konstruk dengan item pengukuran lebih besar daripada ukuran konstruk lainnya, maka hal ini menujukkan bahwa konstruk laten memprediksi ukuran pada blok mereka lebih baik daripada ukuran pada blok lainnya. Adapun nilai Discriminant Validity dengan melihat nilai cross loadings output seperti pada tabel di bawah ini :

Tabel 2. Dicriminant Validity

\begin{tabular}{|l|r|r|r|}
\hline & Produk & $\begin{array}{r}\text { Impulsif } \\
\text { Buying }\end{array}$ & Toko \\
\hline Produk & 0.698 & & \\
\hline Impulsif Buying & 0.389 & 0.732 & \\
\hline Toko & 0.461 & 0.390 & 0.662 \\
\hline
\end{tabular}

Sumber : data diolah

Dari tabel 2 diatas dapat diketahui bahwa perbandingan antara loading factors pada Discriminant Validity terhadap nilai AVE seperti pada produk dengan nilai Discriminant Validity (0.698; 0.646), Impulsive buying $(0.732 ; 0.713)$, Karakteristik Toko (0.662;0.696). Kesemua lebih besar dari korelasi masing-masing konstruk oleh sebab itu dapat disimpulkan bahwa konstruk laten memprediksi ukuran pada blok mereka (dimensi pengukuran) lebih baik. Adapun nilai $\mathrm{R}^{2}$ ialah sebagai berikut :

Tabel 3. Uji R ${ }^{2}$

\begin{tabular}{ccc}
\hline & R Square & $\begin{array}{c}\text { R Square } \\
\text { Adjusted }\end{array}$ \\
\hline Impulsive Buying & 0.343 & 0.337 \\
\hline
\end{tabular}

Sumber : data diolah

Nilai 0.343 pada tabel 3 diatas menyatakan bahwa model memiliki hubungan yang moderat. Nilai 0.343 atau $34.3 \%$ menyatakan bahwa pengaruh brand, dan karakteristik toko memberikan kontribusi sebesar $34.3 \%$ terhadap pembentukan kecenderungan pembelian impulsif individu atau kelompok dan masih terdapat $65.7 \%$ variabel lain yang menjadi pemicu faktor pembelian impulsif yang tidak dibahas dan dimasukkan didalam penelitian ini. Adapun nilai $\mathrm{f}^{2}$ ialah sebagai berikut :

Tabel 4. Nilai $\mathrm{f}^{2}$ Untuk Effect Size

\begin{tabular}{|l|c|c|c|}
\hline & Produk & $\begin{array}{c}\text { Impulsif } \\
\text { Buying }\end{array}$ & Toko \\
\hline Produk & & 0.026 & \\
\hline Impulsif Buying & & & \\
\hline Toko & & 0.013 & \\
\hline
\end{tabular}

Sumber : data diolah

Dari tabel 4 diatas dapat disimpulkan bahwa variabel produk jika diuji secara terpisah terhadap factor pembelian impulsif memiliki pengaruh yang lemah secara parsial, karakteristik toko juga memiliki pengaruh yang sangat lemah jika diuji secara parsial terhadap factor pembelian impulsif. Kesimpulan daripada pengujian secara parsial ini adalah jika melakukan pengujian salah satu variabel terhadap variabel pembelian impulsif maka diasumsikan pengujian tersebut memberikan nilai yang lemah sehingga diharuskan untuk diuji secara bersama-sama untuk mendapatkan keakuratan hasil penelitian. Adapun nilai signifikansi dalam model penelitian ini adalah :

\section{Tabel 5. Nilai t Untuk Effect Size}

\begin{tabular}{lcrr}
\hline & $\begin{array}{l}\text { Standard } \\
\text { Deviation } \\
\text { (STDEV) }\end{array}$ & t Statistics & P Values \\
\hline $\begin{array}{l}\text { Brand -> } \\
\text { Impulsive Buying }\end{array}$ & 0.041 & 3.734 & 0.000 \\
$\begin{array}{l}\text { Toko -> } \\
\text { Impulsive Buying }\end{array}$ & 0.043 & 2.600 & 0.009 \\
\hline
\end{tabular}

Sumber : data diolah

a. Karakteristik Produk memiliki pengaruh yang signifikan terhadap pembelian impulsif sebesar $0.000<0.05$ dan berpengaruh secara positif dengan nilai Thitung sebesar $3.734>0.999 \quad\left(\mathrm{~T}_{\text {tabel }}\right)$ 
dengan standar simpangan baku (standar deviasi) yang kecil yakni 0.041 .

b. Karakteristik Toko memiliki pengaruh yang signifikan terhadap pembelian impulsif sebesar $0.009>0.05$ dan berpengaruh secara positif dengan nilai Thitung sebesar 2.600>0.999 ( $\left.\mathrm{T}_{\text {tabel }}\right)$ dengan standar simpangan baku (standar deviasi) yang kecil yakni 0.043.

\section{Pembahasan}

Fakta yang ditemukan di penelitian ini adalah konsumen Indonesia memilih mall sebagai tempat untuk bersantai bersama teman, mengunjungi bioskop di mall, café di mall atau sekedar makan di mall sebanyak $(29,7 \%)$ memilih untuk sekedar jalan-jalan dan cuci mata (26.2\%). Sedangkan yang memang fokus untuk berbelanja $(7.4 \%)$ dan yang melakukan ketiga aktivitas sekaligus (36.8\%). Hasil tersebut dijelaskan dalam bentuk bagan sebagai berikut :

Di mall saya lebih banyak untuk:
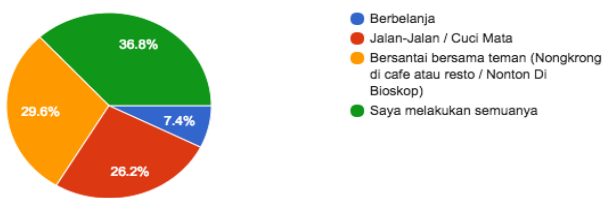

Gambar 5. Sebaran Angket Berdasarkan Alasan Konsumen Memilih Mall

Mall memang diciptakan dengan menawarkan berbagai macam hal yang menarik yang terdapat di sana, bukan hanya menjadi tempat berbelanja, mall juga dapat dikatakan sebagai tempat rekreasi kaum urban.

Di dalam mall sendiri banyaknya produsen yang memproduksi dan menjual barang yang bersifat sama membuat pelaku bisnis itu mencari cara agar dapat menarik perhatian pengunjung tidak hanya bermain disektor pemberian harga potongan dan promo dihari besar seperti yang umum dilakukan, tapi juga tata layout toko desain interior toko baik penempatan musik dan juga penerangan serta penempatan tenaga penjual yang handal dianggap sebagai upaya untuk mendukung hal itu. Karakteristik toko merupakan hal yang membedakan antara satu produsen dengan kompetitornya. Para pembeli beranggapan bahwa produk yang ditampilkan di outlet produsen haruslah memiliki tema yang mewakili produk yang dijualnya, sehingga lingkungan daripada toko tersebut membuat mood yang mendorong seseorang untuk tertarik berbelanja. Umumnya jenis produk yang berada di etalase paling depan adalah produk-produk fashion untuk wanita entah tas, alat kosmetik, sepatu. Produk untuk pria diletakkan di bagian belakang. Tujuan penempatan produk wanita tersebut adalah diyakini untuk menarik konsumen wanita terlebih dahulu sebab wanita memiliki kecenderungan didalam berbelanja cenderung mengabaikan konsekwensi atau tanpa berfikir panjang, hanya didasari perasaan suka dan unik seorang wanita mampu membuat keputusan berbelanja. Hal ini berbanding terbalik dengan pria yang cenderung lebih rasional didalam proses pembelanjaan. Pelayan toko di era modern sekarang ini lebih banyak menggunakan pelayan wanita ketimbang pria sebagai tenaga penjual langsungnya. Entah untuk produk fashion, kuliner, gadget, properti, sampai kendaraan otomotif. Hal tersebut bukan tanpa alasan, tenaga penjual langsung wanita dianggap lebih responsible ketimbang pria, kelebihan lain yang dimiliki pelayan wanita ketimbang tenaga penjual langsung atau pelayan pria ialah kemampuan untuk merayu pelanggan baik pria maupun wanita sehingga konsumen memutuskan untuk berbelanja serta pelayan atau tenaga penjual wanita lebih dianggap nyaman dan tetap sabar untuk ditanya seputar produk yang dijualnya berbeda dengan pelayan atau tenaga penjual pria yang lebih dianggap sulit untuk ditanya seputar produk yang dijualnya.

Temuan yang berasal dari survei responden atau konsumen dan pengunjung mall di Indonesia yang menyatakan bahwa meskipun kehadiran pelayan yang ramah pilihan konsumen di Indonesia didalam berbelanja dimall lebih cenderung suka berkeliling didalam toko tersebut sendirian tanpa didampingi oleh pelayannya, sebanyak 76.7\% berpendapat demikian sedangkan 
sisanya $23.3 \%$ berpendapat lebih suka didampingi oleh pelayan. Hasil tersebut dijelaskan pada bagan dibawah ini :
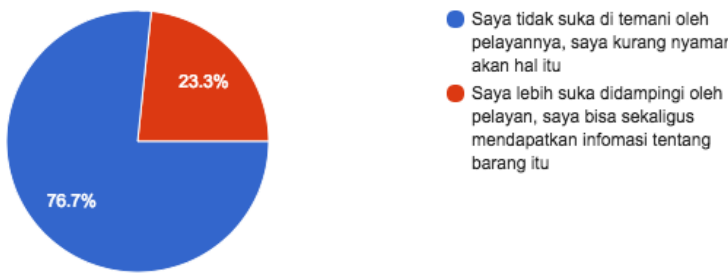

- Saya lebih suka didampingi ole pelayan, saya bisa sekaligus pelayan, saya bisa sekalgus barang itu

Gambar 6. Sebaran Angket Berdasarkan Kecenderungan Konsumen Dalam Berbelanja

Alasan mengapa kecenderungan konsumen mall di Indonesia lebih senang berkeliling sendiri atau mencari barang sendiri didalam toko dikarenakan adalah persoalan risih dan dapat membuat konsumen tersebut tidak betah jika didampingi oleh pelayannya. Konsumen yang mengerti tentang produk yang ia mau beli atau lihat cenderung lebih senang berkeliling sendiri. Konsumen yang sulit memutuskan pilihan mereka akan sebuah produk umumnya lebih senang didampingi oleh pelayan toko disamping mengefesienkan waktu pencarian dan menjatuhkan pilihan akan produk yang dikehendaki, konsumen dengan typical seperti ini tidak hanya puas sekedar membeli barang saja, terkadang mereka dapat menggali informasi mengenai produk tersebut atau untuk meningkatkan keyakinan diri terhadap barang yang dikehendaki. Hasil temuan ini sependapat dengan hasil penelitian Wahida (2010) yang menyatakan bahwa bagi konsumen, seorang pelayan toko yang terlatih dapat mengurangi frustasi konsumennya melalui pemanduan dan mengarahkan konsumen didalam proses belanja

Bagi konsumen mall di Indonesia adalah mayoritas responden cenderung tertarik untuk berbelanja jika pemilihan warna pada desain interior toko adalah berwarna putih (32.6\%), biru (28.7\%), merah (14.1\%), hijau (12.4\%), hitam (10.3), orange (8.4\%), dan kuning $(7.3 \%)$. Hasil teserbut dijelaskan dalam bentuk bagan seperti dibawah ini :
Menurut saya pemilihan warna pada toko dibawah ini adalah sangat baik untuk menarik perhatian konsumen (Jawaban Bisa dipilih lebih dari 1) 933 responses

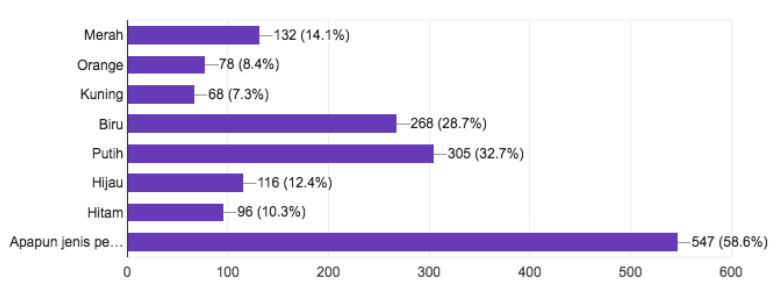

Gambar 7. Sebaran Angket Berdasarkan Warna Pada Desain Interior Toko

Kendatipun demikian konsumen di Indonesia menyatakan bahwa apapun pilihan warna pada dasarnya bergantung kepada tema dari toko tersebut tapi yang terpenting adalah karakter warna tersebut adalah soft. Desain interior pada outlet dengan pemilihan warna putih atau warna yang cenderung soft meningkatkan mood dan minat beli konsumen pada mall di Indonesia. Hasil ini berbanding terbalik daripada survei Kissmetric yang menyatakan bahwa warna hitam, merah, dan biru tua atau dominasi warna gelap yang membuat kecenderungan konsumen menjadi lebih impulsif didalam berbelanja.

Terkait mengenai brand image, kecenderungan anggapan merek bagi konsumen Indonesia direfleksi dari semakin banyak iklan produk tersebut dimuat dimedia atau tidak, atau seberapa banyak pengguna dari produk tersebut dianggap bahwa produk tersebut lebih baik daripada produk yang kurang dipakai oleh banyak orang meskipun anggapan itu tidak sepenuhnya benar. Banyaknya iklan produk tersebut diberbagai media memperkuat keyakinan konsumen bahwa merek yang lebih banyak beriklan adalah produk dengan kualitas yang jauh lebih baik.

Persepsi konsumen mengenai merek tercermin melalui hasil survei di penelitian ini yang menjawab merek dengan harga yang mahal memberikan kualitas yang setimpal (57.1\%), merek yang baik adalah merek yang produknya banyak digunakan orang (18\%), merek yang baik adalah merek yang produknya banyak terpampang di iklan $(24,8 \%)$, dan merek yang baik adalah merek yang informasinya dapat dilihat pada internet 
$(18,2 \%)$. Hasil tesrsebut dijelaskan dalam bentuk bagan seperti dibawah ini :

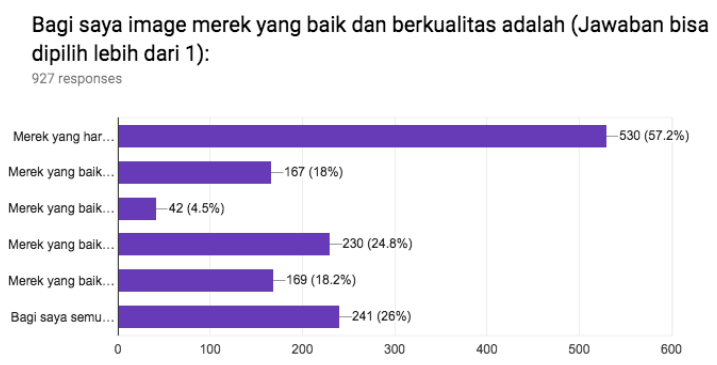

Gambar 8. Sebaran Angket Berdasarkan Persepsi Merek

Dominan daripada hasil survei diatas menyatakan bahwa merek dengan harga yang mahal cenderung memberikan kualitas yang setimpal. Khususnya di Kota Makassar tipikal masyarakat Kota Makassar adalah karakter dengan tipe konsumen yang tidak terlalu peka dengan harga, hal ini berbeda dengan konsumen di Pulau Jawa yang kenaikan harga sedikit saja dapat mempengaruhi keputusan pembelian seseorang. Persepsi kualitas produk juga tercermin daripada konsumen di Indonesia yang menyatakan sebanyak $(39,6 \%)$ berpendapat kualitas barang yang dicari konsumen adalah yang baik meskipun itu sangat mahal.

Variasi jawaban pada hasil sebaran angket dengan pertanyaan "Saya adalah tipe orang yang ketika membeli barang melihat jenis mereknya" yang merupakan sub bagian daripada possesif mereka dengan kecenderungan jawaban berada pada kategori biasa saja (35.9\%), tidak setuju (13.7\%), sangat tidak setuju (1.4\%) atau dengan total variasi jawaban yang dinterpretasikan negatif ini sebanyak $51,4 \%$. Interpretasi jawaban yang positif juga ialah sebanyak $48.6 \%$ variasi jawaban responden kategori yang setuju (33.9\%), sangat setuju (14.7\%) menyatakan sepakat bahwa merek suatu produk memiliki pengaruh terhadap keputusan mereka membeli atau kecenderungan konsumen berperilaku impulsif.

Pertanyaan selanjutnya yakni "Bagi saya merek melambangkan status sosial seseorang yang menggunakannya" variasi jawaban responden menunjukkan kategori jawabannya positif berada pada taraf setuju $(35.4 \%)$ dan sangat setuju (14.6\%) atau secara keseluruhan berjumlah $50 \%$. Sedangkan yang memilih jawaban negatif menjawab biasa saja (33\%), tidak setuju (13.8\%), dan sangat tidak setuju (3.1\%) atau secara keseluruhan juga berjumlah total $50 \%$. Pertanyaan selanjutnya sebagai wujud refleksi daripada persepsi merek terhadap harga yakni sebagai wujud refleksi daripada persepsi merek terhadap harga yakni "Bagi saya merek dengan harga mahal pasti memberikan kualitas yang baik daripada merek dengan harga yang murah" yang merupakan sub dimensi daripada anggapan kualitas produk dengan variasi jawaban responden yaitu positif berada pada kategori setuju (42.6\%), dan sangat setuju (17.8\%) atau dengan jumlah total sebesar $60.4 \%$. Variasi jawaban responden yang negatif yang memilih menjawab biasa saja (25\%), tidak setuju $(13,2 \%)$, dan sangat tidak setuju (1.4\%) dengan jumlah secara keseluruhan adalah 39.6\%. Pertanyaan selanjutnya yang merupakan sub bagian daripada durabilitas merek yakni "Menurut saya merek barang yang ternama haruslah lebih tahan lama" dengan variasi jawaban responden berada pada kategori sangat setuju (44.3\%) dan setuju (43.5\%).

Mengenai produk apa saja yang membuat konsumen di Indonesia dapat berperilaku impulsive adalah pakaian (55.3\%), makanan dan minuman $(47,1 \%)$, parfum, sepatu, tas (33.3\%), aksesoris $(23,4 \%)$, belanja hobby $(20,3 \%)$, gadget dan smartphone $(13,8 \%)$, film $(9.1 \%)$, musik (6.5\%), PC dan laptop (5.4\%), otomotif $(6.4 \%)$, dan video game $(4.3 \%$. Hasil tersebut digambarkan dalam bentuk bagan seperti dibawah ini :

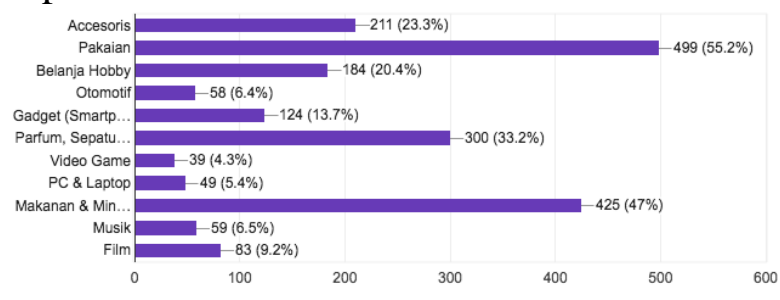

Gambar 9. Sebaran Angket Berdasarkan Produk Yang Dibeli 
Konsumen wanita lebih cenderung impulsif untuk produk pakaian, makanan dan minuman, parfum, tas dan sepatu serta gadget dan smartphone. Sedangkan konsumen pria lebih cenderung impulsif untuk kategori produk belanja hobby, otomotif, PC, laptop, film, otomotif dan video game. Secara garis besar pemilihan produk wanita adalah produk-produk dengan kecenderungan untuk aktualisasi diri sedangkan pemilihan produk bagi pria dengan kecenderungan untuk kepuasan diri. Bagi konsumen dengan pendapatan di bawah 2 juta memilih mall sebagai tempat untuk bersantai dan jalan-jalan sedangkan bagi konsumen mall di Indonesia dengan pendapatan 3 juta - diatas 10 juta menjadikan mall sebagai tempat berbelanja. Sebanyak 58,6\% konsumen atau pengunjung mall di Indonesia berperilaku impulsif didalam berbelanja, 42,4\% masuk dalam kategori pembeli rasional. Konsumen mall di Indonesia jika diperhadapkan pada situasi berbelanja dengan metode penerapan harga misalnya "Diskon hari raya" atau "Buy 1 get 1 free" dominan konsumen dan pengunjung mall di Indonesia memilih bentuk penerapan harga "Buy 1 get 1 free" dan berpotensi membuat konsumen mall di Indonesia berpotensi untuk berperilaku secara impulsif dalam berbelanja. Selanjutnya sebanyak $36,5 \%$, ketimbang pada kondisi penerapan harga "Diskon hari raya" $28.9 \%$. Hal lain yang ada pada konsumen atau pengunjung mall di Indonesia adalah mencari barang dengan harga yang menurutnya terjangkau $(67,6 \%)$, barang tersebut berkualitas meskipun mahal $(46,1 \%)$, keharusan limited edition karena mencerminkan nilai presitisius bagi penggunanya (11,2\%), kemudahan pembeli tersebut mengakses lokasi belanja, dan klaim garansi (20.9\%), dan karena pelayanannya (15\%).

\section{Kesimpulan}

Karakteristik Toko dan karakteristik produk memiliki pengaruh yang signifikan terhadap perilaku pembelian impulsif konsumen mall di Indonesia. Sebanyak $58,6 \%$ konsumen atau pengunjung mall di
Indonesia berperilaku impulsif di dalam berbelanja. 42,4\% masuk dalam kategori pembeli rasional, Konsumen baik pria maupun wanita memiliki potensi yang sama terhadap perilaku impulsif di dalam berbelanja. Konsumen pria cenderung berperilaku impulsif terhadap produk yang yang menginterpretasikan kepuasan diri,, sedangkan konsumen wanita cenderung berperilaku impulsif terhadap produk yang menginterpretasikan aktualisasi diri. Sebanyak 58,6\% Konsumen atau pengunjung mall di Indonesia berperilaku impulsif didalam berbelanja. $42,4 \%$ masuk dalam kategori pembeli rasional.

Khusus untuk konsumen di Kota Makassar masuk dalam kategori konsumen yang memiliki kecenderungan relatif tidak terlalu peka terhadap harga suatu barang, Konsumen di Pulau Jawa adalah konsumen yang sangat peka terhadap perubahan harga. Konsumen baik pria maupun wanita memiliki potensi yang sama terhadap perilaku impulsif didalam berbelanja. Konsumen pria cenderung berperilaku impulsif terhadap produk yang yang menginterpretasikan kepuasan diri, sedangkan konsumen wanita cenderung berperilaku impulsif terhadap produk yang menginterpretasikan aktualisasi diri.

\section{DAFTAR PUSTAKA}

Aditya, Halim P. 2012. "Analisis Pengaruh Harga, Data Demografi, Promosi terhadap Kecenderungan Pembelian Impulsif Dan Pengaruhnya Terhadap Budaya Konsumerisme Relatif Pada Konsumen KFC Kota Makassar". Tesis; Universitas Muslim Indonesia

Andina Meryani, 2011. Konsumen Kian Impulsif, Mal Kian Subur.

CNN, Indonesia.2015 “Generasi Millenial RI Paling Impulsif Belanja Barang Mewah"https://www.cnnindonesia.co $\mathrm{m} /$ ekonomi/20151102182452-92 88999/generasi-millenial-ri-palingimpulsif-belanja-barang-mewah/. 
Crawford, G., \& Melewar, T. C. (2003). The importance of impulse purchasing behavior in the international airport environment. Journal of Consumer Behavior, 3(1), 85-98.

Dholakia, U. M. (2000). Temptation and resistance: An integrated model of consumption impulse formation andenactment. Psychology \& Marketing, 17(11), 955-982.

Ditmar, Helga. 1996. Objects, Decision Considerations and Self-Image in Men's and Women's Impulse Purchases, Acta Psychologica, 93: 187-206.

J. Drury., (2000), Self-image - is it in the bag? A qualitative comparison between ordinary and excessive consumers, Journal of Economic Psychology 21 (2) hal. 109-142.

Engel, J.E, Blackwell, R.D. \& Miniard, P.W.1995. Consumer Behavior. 8ed . Orlando; The Dryden Press

Kim, J. (2003). College Students' Apparel Impulse Buying Behaviors in Relation to Visual Merchandising, Doctoral Dissertation, University of Georgia.

Kotler, Phillip. 2009. Manajemen Pemasaran (terjemahan). Edisi Millenium, Jilid 1. PT. Prenhallindo. Jakarta.

Luo, X. (2005). How does shopping with others influence impulsive purchasing. Journal of Consumer Psychology, 15(4), 288-294.

Marketing.co.id. 2017 "Karakter dan Perilaku Khas Konsumen Indonesia" http://www.marketing.co.id/karakterdan-perilaku-khas-konsumenindonesia/

MARS Indonesia, 2015. Perilaku Belanja Konsumen Indonesia 2015.
Nielsen, 2013. Konsumen Indonesia Paling Doyan Belanja.

Wahida, Shinan. T. 2010 "Impulse Purchasing: A Literature Overview" ASA University Review, Vol 4 No. 2 July December 2010

Wood, M. (1998). Socio-economic Status, Delay of Gratification, and Impulse Buying. Journal of Economic Psychology, 19, 295-320.

Stern, Hawkins 1962, "The Significance of Impulse Buying Today, "Journal of Marketing, 26 April 59-62

Clover, Vernon T. 1950, "Relative Importance of Impulse Buying in Retail Stores, Journal of Marketing 25 July 66-70

Abratt, R., \& Goodey, S. D. (1990). Unplanned Buying and In-Store Stimuli in Supermarkets. Managerial and Decision Economics, 11(2), 111121

Rook, Ddennis W. 1985. "The Ritual Dimensions of Consumer Behavior," Journal of Consumer Research, 12 December 251-264

Han, Y. K., Morgan, G. A., Kotsiopulo, A., \& Kang-Park, J. (1991). Impulse buying behavior of apparel purchasers. Clothing and Textiles Research Journal, 9(3), 15-21.

Hoch, S. J., \& Loewenstein, G. F. (1991). Time-inconsistent preferences and consumer self-control. Journal of Consumer Research, 17(4), 492-507.

Jones, M., Reynolds, K., Weun, S., \& Beatty, S. (2003). The product specific nature of impulse buying tendency. Journal of Business Research, 56(7), 505-511 